\title{
On the contrast and research of maximum power point tracking control in the Microgrids PV system
}

\author{
Bo Hu , ZaiLin Piao \\ Information \& Electric Engineering College \\ Shenyang Agricultural University \\ Shenyang, 110866, China \\ Boer5109@sohu.com, piaozl@china.com
}

\begin{abstract}
In microgrids operation, photovoltaic power generation system need to quickly and accurately for maximum power point tracking (MPPT), namely MPPT technology, because of the diversity of the control method, its control effect is different, a realization of process is also great difference. And because the current maximum power point tracking method is not enough accurate and mature, which led to the photovoltaic system power loss, this paper expounds the advantages and disadvantages of all kinds of tracking control method, in light of the maximum power point tracking control theory, and sums up the mathematical model of optimization, seeking the optimal control method. The paper is to explore maximum power point tracking control method development mentality, to look forward the research direction of the microgrids PV system.

Keywords-Microgrids; PV system; Maximum power point tracking(MPPT) ; Power loss.
\end{abstract}

\section{INTRODUCTION}

Nowadays, energy shortage, environment deterioration are increasingly serious global problem. Solar energy with its advantages including cleaning, no pollution, and inexhaustible, is paid more and more people's attention. But the solar energy cell transformation efficiency is low, installation cost and module price high also increases the cost of the system, so that there are the serious restriction in the photovoltaic system promotion and effective use.

In order to improve the whole system transformation efficiency and effective complete system cycle cost return, photovoltaic system should ensure that the solar energy cell working in output power curve of maximum point, according to the solar module working state real time control the output current and voltage, forcing its work in the output power of the biggest point near, this process is the maximum power point tracking. MPPT control method is to improve the efficiency of photovoltaic module effective way. MPPT control method commonly used in constant pressure tracking methods, open circuit voltage method, the disturbance observation method and conductance increment method, etc., disturbance observation method and conductance incremental method is a common method. Disturbance observation method for simple calculation, without solar cell module of the specific parameters etc.
A. The analysis on the solar cell output characteristic curve

Solar panels of the equivalent circuit diagram can be as shown in figure:

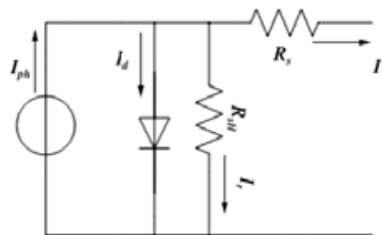

Fig.1 Solar panels of the equivalent circuit diagram

From the Fig.1can come to the output current expression:

$$
I=I_{S C}-I_{0}\left\{\exp \left[\frac{q\left(V+I R_{S}\right)}{A K T}\right]-1\right\}-\frac{V+I R_{S}}{R_{S h}}
$$

Among them: $I$ for output current; $I_{S C}$ for short circuit current; $I_{0}$ for reverse saturation current; $V$ as output voltage; $q$ for electronic charge; $K$ for the Boltzmann constant; $T$ for absolute temperature; $A$ for photovoltaic battery ideal factor; $R_{S}$ for series resistance; $R_{S h}$ for parallel resistance.

\section{B. The research on Photovoltaic array simulation model}

According to the formula establish a MATLAB/SIMULINK Photovoltaic array simulation model,

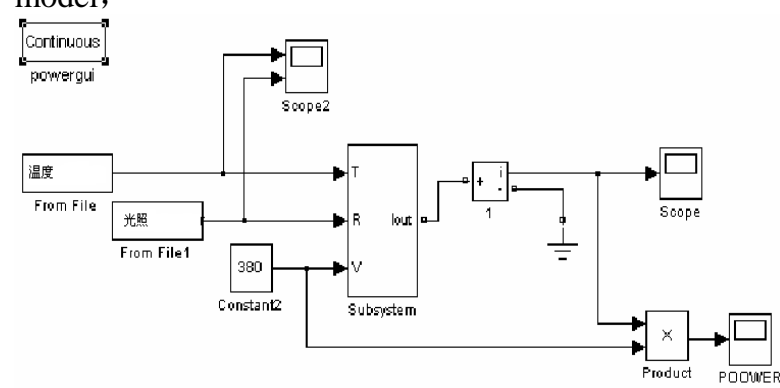

Fig.2 Photovoltaic array simulation model 


\section{On CONTROL METHOD of the Photovoltaic array of maximum power point TRACKING}

Photovoltaic cell is a kind of nonlinear dc source, fig.3 and fig.4 show a photovoltaic array that are given respectively and different illumination intensity and different cell temperature of photovoltaic array output characteristic curve. From fig. 3 and fig.4, we can conclude that when the outside world natural conditions change, photovoltaic array output characteristic will change, the output power and the maximum power point also corresponding change. And, light intensity change main influencing array output current, and cell junction temperature change main influencing output voltage. When the working voltage of pv array is located in the maximum power point voltage $\mathrm{U}$, photovoltaic array is output maximum power.

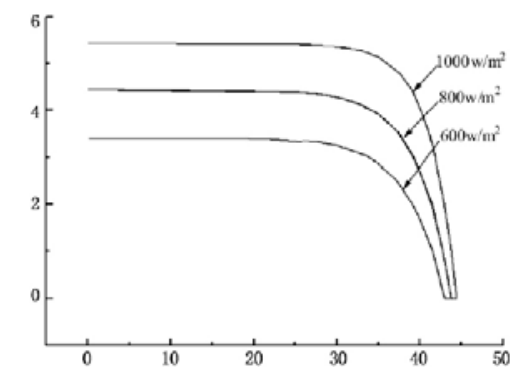

Fig.3 Typical photovoltaic battery $I-V$ properties curve with solar radiation intensity change

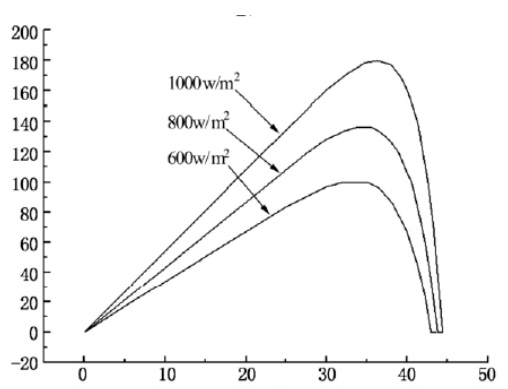

Fig.4 Typical photovoltaic battery $P-V$ properties curve with solar radiation intensity change

With the external natural conditions change, photovoltaic array output characteristic will change. Sunshine intensity change main influencing output current, and cell junction temperature change main influencing output voltage. Moreover, when photovoltaic array output voltage is low, with voltage change, the change of output current is not big, photovoltaic array similar to a constant current source; When the voltage exceeds a critical value continue to rise, current fell sharply, the photovoltaic array similar to a constant voltage source. Photovoltaic array output power as output voltage increases have a first after the rise of process, the turning point is the maximum power Pmpp output point. Therefore, in the temperature and radiation intensity are changing environment, need by adjusting the photovoltaic array to inherit the equivalent load, real-time adjustment of pv array working point, make pv array always stay in the maximum power point, in order to realize to the micro net pv power generation system MPPT control.

\section{COMMONLY USED MPPT CONTROLMETHOD IN} MICROGRIDS PV SYSTEM

\section{A. At the early stage of the MPPT control method}

The earliest on photovoltaic array MPPT technology research mainly is the constant voltage tracking method, open circuit voltage method, the actual measuring method, and the short circuit current method, etc. Because of its circuit is simple, economic and practical, so although it is no longer the mainstream detection method, but there exist still in some areas played a very good role.

Constant voltage tracking method is a relatively simple maximum power point tracking methods, this method is actually a stable voltage control, when the method but not the influence of temperature on photovoltaic array into consideration, its essence is not maximum power point tracking, because of temperature change is bigger area, this method cannot in all external environment for the whole tracking.

Photovoltaic array group legal is relatively early proposed a method, this method is mainly according to different load to adjust the number of photovoltaic array in series connection and parallel connection, so as to meet the photovoltaic array work in the maximum power point. But this method has a poor, not with the surrounding environment change timely make corresponding adjustment.

The actual measurement method is to use additional photovoltaic array battery to establish a reference model, this method may avoid because components and cell aging and lose accuracy, but for small power system, and its cost is too high, and for high power system, and the need to consider the shadow covering problems.

Now, the micro net pv system maximum power point tracking problem, the most meaningful is still photovoltaic materials and photovoltaic array mechanical tracking method, i.e., using switch tube on-off to adjust the voltage to the duty ratio for photovoltaic array of the highest conversion efficiency of the method.

\section{B. Finding the optimal maximum power point tracking control method improvement}

In many of the maximum power point tracking methods, disturbance observation method and conductance incremental method is a common method. The test method is not direct detection of external environment factors changes, but direct measurement of pv array of voltage and current change of maximum power point tracking.

- Disturbance observation method

Disturbance observation method, also known as climbing method, is the most commonly used MPPT control method. The basic working principle is periodically for photovoltaic array output voltage add a small voltage disturbance, compare the current output power and output power before the disturbance of the size, if power increases, the continue to disturbance, Conversely, criterion the direction change disturbance. In other words, the input disturbance makes 
output power change, working point is located in the maximum power point of the left side, should continue to increase the disturbance, make the working point to continue to the right that is maximum power point change of direction. And if the input disturbance makes output diminish, working point should be located in the right of the maximum power point, should reduce disturbance, make the working point move to the left, so that circulation disturbance looking for, until find maximum power point.

In fact based on the same train of thought, since can on photovoltaic array output voltage for disturbance, its output current can also be carried out disturbance, to achieve maximum power point tracking. Disturbance observation method for principle easy to understand, calculation is simple, and it is unnecessary to consider solar cell module specific parameter etc is widely used, but its shortcoming is even arrived near the maximum power point, the disturbance will not stop, in the maximum power point nearby oscillation, will lead to the loss of part of the power, disturbance of step length size also determines the maximum power point tracking speed. And for the disturbance observation method shortcomings, variable step size disturbance observation method is a practical method.

- Conductance increment method

Incremental conductance method is the use of pv array curve is a single peak curve, the maximum power point principle to control the maximum power point method. For photovoltaic power output, output voltage. Therefore has the following criteria:

$$
\left\{\begin{array}{l}
\frac{d P}{d U}=0, \text { work in the maximum power point; } \\
\left.\frac{d P}{d U}\right\rangle 0 \text {, work in the maximum power point on the left } ; \\
\frac{d P}{d U}\langle 0 \text {, work in the maximum power point on the right。 }
\end{array}\right.
$$

Because:

$$
\frac{d P}{d U}=\frac{d U I}{d U}=I+U \frac{d I}{d U}
$$

On the type can be rewritten for:

$\frac{I}{U}+\frac{d I}{d U}=0$, work in the maximum power point;

$\left\{\frac{I}{U}+\frac{d I}{d U}>0\right.$, work in the maximum power point on the left ;

$\frac{I}{U}+\frac{d I}{d U}\langle 0$, work in the maximum power point on the right。

This will through the judgment $\frac{I}{U}+\frac{d I}{d U}$ that is $G+d G$ (for $G$ conductivity) symbol to judge photovoltaic array whether there is maximum power point.

From the above method, derived the criterion:

By: $U d I=-I d U$

May: $\Delta I=U d I$ current power difference score $\Delta U=-I d U$ Voltage power difference score

So, $\Delta U=\Delta I$ the algorithm of first difference
In the optimization process,

$$
d I(k)=I(k+1)-i(k)=\sum_{i=256 k}^{256(k+1)} I_{i} / 256-\sum_{i=256(k-1)}^{256(k-1)} I_{i} / 256
$$

$\left\{\begin{array}{l}1 . \Delta I(k)=\Delta U(k), \text { in the power point, keep active power } \\ 2 . \Delta I(k)\rangle \Delta U(k), \text { output power increase direction for voltage increase } \\ \text { and decrease current direction, must reduce the system active output } \\ \text { can cause the system to return to maximum power point. } \\ 3 . \Delta I(k)\langle\Delta U(k), \text { the contrary is the case to two }\end{array}\right.$

$$
\begin{gathered}
d I(k)=I(k+1)-i(k)=\sum_{i=256 k}^{256(k+1)} I_{i} / 256-\sum_{i=256(k-1)}^{256(k-1)} I_{i} / 256 \\
\Delta I(k)=U(k+1) d I(k) \\
\Delta U(k)=-I(k+1) d U(k)
\end{gathered}
$$

Through the above analysis, we can see that all kinds of tracking control method has its own advantage at the same time, the existence of the inevitable shortcomings, because of photovoltaic power generation maximum power point tracking control method development is not very perfect, the technology has not been fully mature, so photovoltaic array maximum power point tracking control method also has extensive research prospects and development space.

\section{CONCLUSION}

Although photovoltaic array maximum power Point tracking control is a complicated comprehensive technology, but with the modern electronic technology and intelligent processing method of development, the realization of PV array MPPT control is provided abundant theoretical basis and new train of thought, and is to achieve a lot of application results.

Modern application Mathematics and intelligent processing method of booming development, solves the photovoltaic array maximum power point tracking the complicated problems and provides a wealth of theory for according to new ideas, at present in the field has made a lot of achievements. How to make all kinds of maximum power point tracking control methods for Organic combination, learn from each other, so that it can better meet the actual demand. As the solar energy and other renewable energy utilization of booming development, photovoltaic array is to be the most.

\section{REFERENCES}

[1] G. Y. Bo, L. Wuhua, Z. Yi, and H. Xiangning, "Design and analysis of a gridconnectedphotovoltaic power system," Power Electron., IEEE Trans.,vol. 25, no. 4, pp. 992-1000, Apr. 2010.

[2] F. Katiraei, R. Iravani, N. Hatziargyriou, and A. Dimeas, "Power and energy magazine,” IEEE, vol. 6, no. 3, pp. 54-65, May/Jun. 2008.

[3] H. Patel and V. Agarwal, "Maximum power point tracking scheme for PVsystems operating under partially shaded conditions," IEEE Trans. Ind.Electron., vol. 55, no. 4, pp. 1689-1698, Apr. 2008.

[4] HUSSEIN A, HIRASAWA K, HU J, et al . The dynamicperformance of photovoltaic supplied dc motorfed from DC DC converter and controlled by neuralnetworks [C] .International Joint Conference on NeuralNetworks, 2002. 
[5] M. G. Villalva, J. R. Gazoli, and E. R. Filho, "Comprehensive approach tomodeling and simulation of photovoltaic arrays," Power Electron., IEEETrans., vol. 24, no. 5, pp. 1198-1208, May 2009.

[6] T. Esram, J. W. Kimball, P. T. Krein, P. L. Chapman, and P. Midya, "Dynamic maximum power point tracking of photovoltaic arrays using ripple correlation control,” Power Electron., IEEE Trans., vol. 21, no. 5,pp. 1282-1291, Sep. 2006.

[7] T. L. Kottas, Y. S. Boutalis, and A. D. Karlis, "New maximum power point tracker for PV arrays using fuzzy controller in close cooperation with fuzzy cognitive networks,” Energy Convers., IEEE Trans., vol. 21,no. 3, pp. 793-803, Sep. 2006.

[8] Masoum M A S, Dehbonei H, Fuchs E F. Theoretical and experimental analyses of photovoltaic systems with voltageand cur-rentbased maximum power-point tracking[J]. IEEE Transac-tions on Energy Conversion, 2002, 17(4): 514-522.
[9] Egiziano L, Femia N, Granozio D, et al. Photovoltaic inverters with Perturb\&Observe MPPT technique and one-cycle control[C]\| Proceedings of IEEE International Symposium on Cir-cuits and Systems. Island of Kos, Greece: IEEE, 2006: 3718-3721.

[10] L. Y. Wei and K. Ching-Nan, "An accurate power control strategy forpower-electronics-interfaced distributed generation units operating in alow-voltage multibus microgrid," Power Electron., IEEE Trans., vol. 24,no. 12, pp. 2977-2988, Dec. 2009.

[11] M. G. Villalva, J. R. Gazoli, and E. R. Filho, "Comprehensive approach to modeling and simulation of photovoltaic arrays," IEEE Trans. Power Electron., vol. 24, no. 5, pp. 1198-1208, May 2009.

[12] Article in a conference proceedings:N. Femia, G. Petrone, G. Spagnuolo, and M. Vitelli, "A technique for improvingP\&O MPPT performances of double-stage grid-connected photovoltaicsystems," Ind. Electron., IEEE Trans., vol. 56, no. 11, pp. 4473-4482, Nov. 2009. 